\title{
A SIMPLE AND RAPID METHOD FOR URINARY ACETONE ANALYSIS BY HEADSPACE/GAS CHROMATOGRAPHY
}

\author{
Danielle Palma de Oliveira* \\ Departamento de Análises Clínicas, Toxicológicas e Bromatológicas, Faculdade de Ciências Farmacêuticas de Ribeirão Preto, \\ Universidade de São Paulo, Av. do Café, s/n, 14040-903 Ribeirão Preto - SP, Brasil \\ Maria Elisa Pereira Bastos de Siqueira \\ Departamento de Análises Clínicas, Universidade Federal de Alfenas, Rua Gabriel Monteiro da Silva, 714, 37130-000 Alfenas \\ - MG, Brasil
}

Recebido em 31/5/06; aceito em 9/11/06; publicado na web em 6/8/07

\begin{abstract}
Urinalysis of acetone is important to monitor workers occupationally exposed to acetone and/or isopropanol, as well as in diagnosis of some diseases related to lipid metabolism impairment. This work shows a sensitive, simple and rapid static headspace-gas chromatographic procedure for quantitative determination of acetone in urine. The method was applied to measure acetone in 207 samples from general population volunteers, resulting in a mean level of $1.12 \mathrm{mg} / \mathrm{L}( \pm 0.47)$ and a range of $0.20-1.95 \mathrm{mg} / \mathrm{L}$. The method is reproducible and reliable, making it suitable for routine analysis of acetone in urine.
\end{abstract}

Keywords: acetone; isopropanol; headspace/gas chromatography.

\section{INTRODUCTION}

Urinary acetone (UAc) is an internal dose indicator recommended for biomonitoring workers exposed to acetone and isopropanol ${ }^{1}$ due to its good correlation with environmental solvent levels ${ }^{2-6}$. It can also be useful for the diagnosis of diseases related to the utilization of lipids such as diabetes mellitus I and for the assessment of early damage due to lipid peroxidation caused by oxidative stress $\mathrm{s}^{4,6-8}$.

Acetone is a solvent widely used in various industrial processes such as the manufacture of strengthened plastic fibers and shoes, among others $5,9,10$. The human sources of acetone emission into the environment include sewage disposal, industrial leaching, and emission from automobiles and turbines ${ }^{11-13}$.

This substance occurs as a component of normal metabolism in blood, urine and air exhaled by humans. Since the endogenous formation of acetone is closely linked to the stored fats utilization as a source of energy, endogenous levels may vary according to individual health, nutrition and activity levels ${ }^{5,10,14-18}$.

Isopropanol is a low-cost solvent with numerous industrial applications as an extracting solvent, purifying agent, and paint, varnish and oil diluent, among other ${ }^{19-21}$. In the human organism this alcohol is biotransformed to acetone through the enzyme alcohol dehydrogenase $\mathrm{e}^{22-24}$.

The static headspace technique is extensively used to determine volatile substances s, $3,17,25-28$. This technique is simple, requires little sample handling and eliminates non-volatile interferents that might contaminate the GC injector and FID detector. The critical point is the equilibrium between the condensed phase and the vapor phase ${ }^{25-29}$ and several parameters must be optimized to guarantee maximum analyte recovery and sensitivity of the method. Since the determination of urinary acetone is of interest in various situations, the objective of the present study was to optimizing a rapid and low cost technique that could be applied in clinical and toxicological routine analysis in laboratories with limited resources, establishing the better conditions to extract AcU by static headspace and to quantify by GC/FID.

*e-mail: dpalma@usp.br

\section{EXPERIMENTAL}

\section{Urine samples}

Samples used for the determination of acetone were obtained from 207 healthy volunteers not occupationally exposed to acetone and/or isopropanol, with different gender, smoke and drinking habits, with ages varying between 18 to 70 years old. This information was obtained using a questionnaire. After collection, the samples were immediately transferred to headspace flasks containing anhydrous sodium sulfate, sealed and stored in the refrigerator until acetone determination, which was carried out on the same day.

The research protocol was approved by the Research Ethics Committee of the Federal University of Alfenas, where the samples were collected and the analyses were processed.

\section{Standards and equipment}

Solutions of acetone $\left(\right.$ Merck $\left.^{\circledR}\right)$ and n-propanol $\left(\right.$ Merck $\left.^{\circledR}\right)$ at $10 \mathrm{~g} /$ $\mathrm{L}$ were prepared in distillated water and stored at $4{ }^{\circ} \mathrm{C}$ (stable for one month, data not shown). Standard solutions of 0.1 to $5.0 \mathrm{mg} / \mathrm{mL}$ were prepared daily, just before use. The urinary acetone concentration was analyzed using a gas chromatograph $\mathrm{CGS}^{\circledR}$ - 1000 DPC model equipped with a Carbowax CG $745^{\circledR}$ column $(30 \mathrm{~m}$ x $0.53 \mathrm{~mm})$ and a flame ionization detector, with IQ (Integration Quality) for integration and processing of the chromatograms. After several tests, the optimized GC conditions were: temperatures of the injector and detector respectively, $150{ }^{\circ} \mathrm{C}$ (in splitless mode) and $180{ }^{\circ} \mathrm{C}$. The oven temperature was kept isothermally at $90{ }^{\circ} \mathrm{C}$, using nitrogen as carrier gas $(8 \mathrm{~mL} / \mathrm{min})$. The internal standard was n-propanol, and the relative retention time (acetone/n-propanol) was 0.47 .

\section{Optimization of the static headspace conditions}

Studies were carried out to establish the best extraction conditions for the method taking into account the various factors that could 
affect the technique. For this step, urine samples were prepared from pooled urine from healthy individuals not exposed to chemical substances excreted as acetone and transferred to appropriate sealed flasks: a) heating time: 5, 10, 15 and 20 min were evaluated; b) heating temperature: $70,75,80,85,90$, and $95{ }^{\circ} \mathrm{C}$ were tested for samples kept in an oven for $20 \mathrm{~min}$; c) effect of salt addition: samples from pooled urine were kept at $90{ }^{\circ} \mathrm{C}$ for 20 min with no addition of salt and with anhydrous sodium sulfate or sodium chloride; d) sample volume: 2, 3 and $5 \mathrm{~mL}$ urine kept at $90{ }^{\circ} \mathrm{C}$ for $20 \mathrm{~min}$ were tested, with the addition of anhydrous sodium sulfate.

\section{Method}

The following procedure was used for the method optimization and for the determination of acetone in real samples: $2 \mathrm{~g}$ anhydrous sodium sulfate and $0.2 \mathrm{~mL}$ internal standard were added to $2 \mathrm{~mL}$ urine in a headspace vial which was sealed and heated to $90{ }^{\circ} \mathrm{C}$ for $20 \mathrm{~min} ; 0.5 \mathrm{~mL}$ of the gas phase was injected into the GC apparatus.

The effect of the biological matrix was evaluated by comparing the curves from water and urine spiked with acetone concentrations between 0.1 and $5.0 \mathrm{mg} / \mathrm{L}$. The analytical curve in urine was prepared for each group of ten samples analyzed, and the acetone concentration naturally present in the pooled urine used for the addition of the standards was subtracted.

The detection limit (LOD) was considered to be the minimum concentration determined with confidence, i.e., differing from zero with a signal/noise ratio $=3$, and was obtained by successive dilutions of $0.1 \mathrm{mg} / \mathrm{L}$ acetone sample. The quantification limit (LOQ) was the lowest concentration that could be measured with adequate precision, i.e., with an imprecision evaluated by a coefficient of variation of less than $10 \%$ and obtained by the addition of the acetone standard to urine $(0.1 \mathrm{mg} / \mathrm{L})$ and by successive sample dilutions.

Intra-assay precision was evaluated in urine samples with no acetone addition and spiked with 1.0 and $3.0 \mathrm{mg} / \mathrm{L}$ (10 replicates/ concentration). Day-by-day precision was determined in same samples for ten consecutive days.

Stability was studied in samples with no acetone addition and spiked with 1.0 and $3.0 \mathrm{mg} / \mathrm{L}$ acetone, under the following conditions: a) ambient temperature $\left(22 \pm 2{ }^{\circ} \mathrm{C}\right)$ and under refrigeration $\left(4{ }^{\circ} \mathrm{C}\right)$ : the samples were analyzed at time zero and 6 , 12,24 and $48 \mathrm{~h}$ later; b) freezer $\left(-20^{\circ} \mathrm{C}\right)$ : the samples were stored in aliquots and analyzed over a period of 10 consecutive days and after 15 and 30 days.

\section{RESULTS AND DISCUSSION}

The optimized GC method, allowed a satisfactory separation between the analyte and the internal standard, as can be observed in the chromatographic profile, illustrated in Figure 1.

Figure 2 shows the results for UAc headspace extraction. The area of acetone peak was the parameter used to establish the best analytical condition. A longer time of flask incubation in the oven increased the area of the acetone peak in $520 \%$ comparing 5 min to $20 \mathrm{~min}$, as can be seen in Figure 2a. This time (20 min) was chosen for the analysis not only because the better recovery of the analyte, but also because it did not increased too much the time of extraction.

The heating temperature was evaluated in order to determine the ideal for acetone volatilization. The initial temperature $\left(70^{\circ} \mathrm{C}\right)$ was close to the boiling acetone point $\left(63^{\circ} \mathrm{C}\right)$, and the highest temperature used was $95{ }^{\circ} \mathrm{C}$. Figure $2 \mathrm{~b}$ illustrates the area of the acetone peak increased in $306 \%$ with the increase of the temperature when the lowest temperature was compared to the highest. However, at $95{ }^{\circ} \mathrm{C}$ significant water volatilization occurs, impairing the

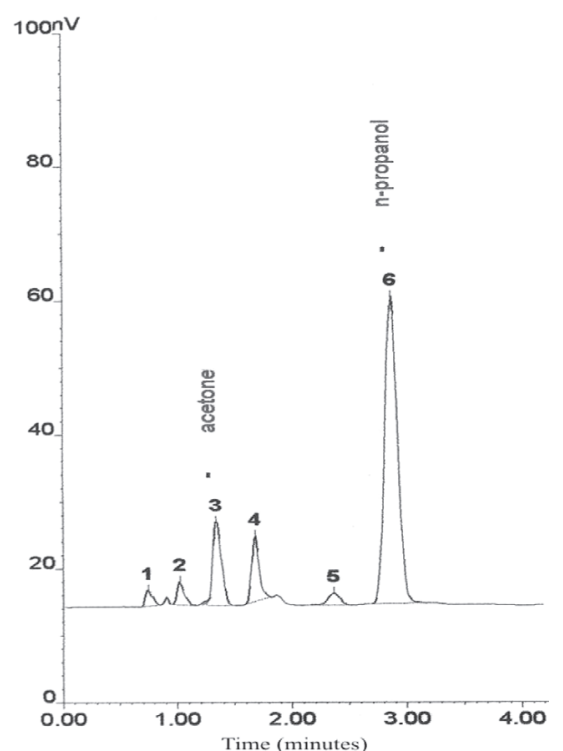

Figure 1. Chromatogram of a urine sample containing acetone and $n$ propanol (IS)
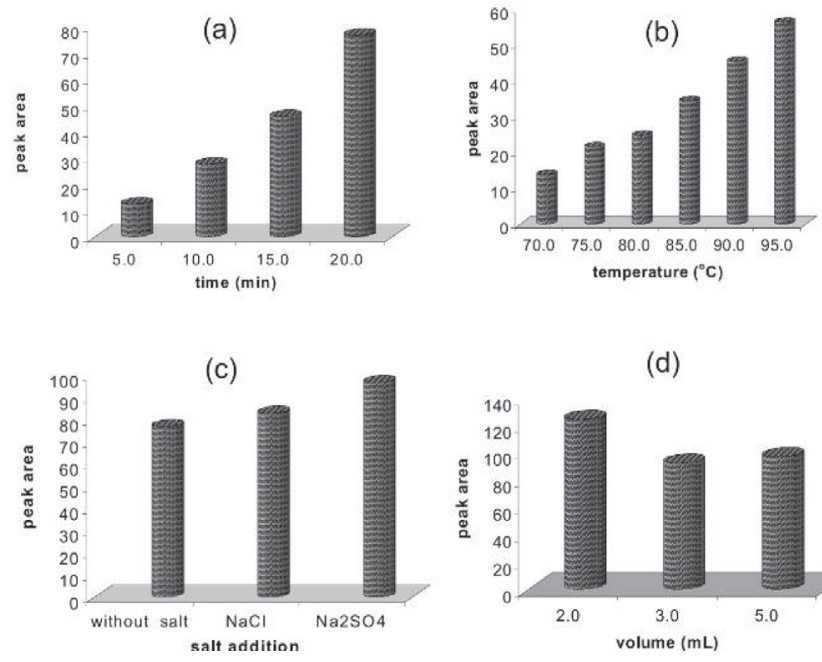

(d)

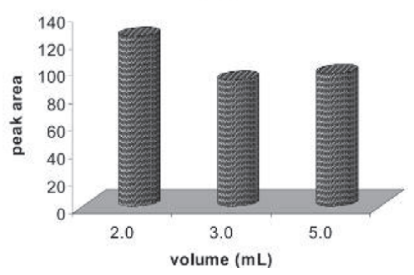

Figure 2. Effect of heating time (a), temperature (b), salt addition (c) and sample volume $(d)$ on acetone resulting peak areas

analyses and reducing performance of the chromatographic column. So, the temperature of $90{ }^{\circ} \mathrm{C}$ was used for the analysis, showing good sensitivity and precision.

Salt addition was studied to determine the salting out effect on analyte extraction, as indicated by some investigators who use headspace technique for several volatile chemicals extraction ${ }^{26,27,29,30}$. According to $\operatorname{Seto}^{29}$ the solubility of many non-electrolyte compounds is reduced by salt addition due to an increase in the activity coefficient (y). Both anhydrous sodium sulfate and sodium chloride elicited this effect, but sodium sulfate showed higher sensitivity, with an increase of $26 \%$ in the peak acetone area compared to no salt addition, as opposed to $7 \%$ for sodium chloride (Figure 2c).

The sample volume of $2 \mathrm{~mL}$ was chosen because it presented a more effective volatilization of the analytes compared to the other volumes tested (Figure 2d), probably due to the greater free space in the vial available for the vapors. The variation observed between 3 and $5 \mathrm{~mL}$ was small, only $5 \%$, but sensitivity increased by $28 \%$ when $2 \mathrm{~mL}$ was used compared to $5 \mathrm{~mL}$.

The complex composition of the biological matrix can strongly affect the headspace technique since the various components can 
alter volatilization of the analytes ${ }^{26,27}$. The effect of matrix on UAc determination can be observed in Figure 3. Biological matrix interference (Figure 3) was found: linear coefficients (intercepts) and the angular coefficients (slope) from curves prepared in water and urine were not similar. Thus, the calibration curves for acetone quantification in the general population were obtained using standards added to urine.

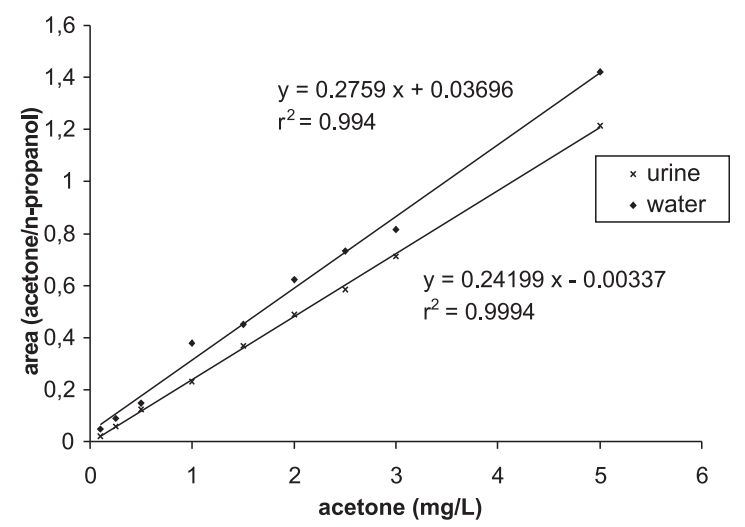

Figure 3. Analytical curves from urine and water spiked with acetone standards

The method was linear from 0.1 to $5.0 \mathrm{mg} / \mathrm{L}$ acetone in urine (Figure 3 ). The concentration range was chosen according to the backgrounds levels variation ${ }^{5,17,26,28,31-34}$.

The LOQ obtained was considered satisfactory since all samples showed results above this value. The LOD, equal to the LOQ, was of $0.1 \mathrm{mg} / \mathrm{L}$, with a coefficient of variation of $7 \%$ for ten replicates. The mean value of the CV's were: $4.8 \%$ for the intra-assay precision and $6.8 \%$ for day-by-day precision.

Acetone in urine showed a slight fall (mean $17 \%$ in $48 \mathrm{~h}$ ) at room temperature. At this temperature peaks of other components were observed, probably formed in the sample, with retention times close to acetone, leading to overlap, with loss of resolution and difficulty in area integration. Acetone remains stable for at least 12 hours when storing urine at $4{ }^{\circ} \mathrm{C}$ and for at least ten days when kept at $-20^{\circ} \mathrm{C}$ (mean $\mathrm{CV}=6 \%$ ), temperature recommended by some authors ${ }^{3,5,15,26,31,33,35}$.

Urinary acetone in general population (Table 1), expressed in $\mathrm{mg} / \mathrm{L}^{1,15}$, was similar to the background values published by some investigators in another countries, ranging from 0.84 to $3.85 \mathrm{mg}$ /

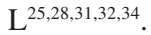

Table 1. Acetone in urine $(\mathrm{mg} / \mathrm{L})$ in a general population

\begin{tabular}{lccc}
\hline & $\mathrm{n}$ & experimental range & Mean* \pm SD \\
\hline total population & 207 & $0.20-1.95$ & $1.12 \pm 0.47$ \\
women & 116 & $0.30-1.95$ & $1.04 \pm 0.35$ \\
men & 91 & $0.88-1.32$ & $1.10 \pm 0.33$ \\
until 25 years old & 59 & $0.30-1.89$ & $1.04 \pm 0.36$ \\
26 - 45 years old & 79 & $0.55-1.95$ & $1.06 \pm 0.35$ \\
above 46 years old & 69 & $0.53-1.72$ & $1.07 \pm 0.32$ \\
\hline
\end{tabular}

* no statistical differences between subgroups males/females or age groups

In conclusion, the proposed method is rapid, simple, low cost and permits its application with confidence to urine acetone determination in several situations where this analysis is requested.

\section{REFERENCES}

1. ACGIH - American Conference of Governmental Industrial Hygienists; Threshold limit values for chemical substances and physical agents. Biological exposure indices, ACGIH: Cincinnati, 2001.

2. DiVincenzo, G. D.; Yanno, F. J.; Astill, B. D.; Am. Ind. Hyg. Assoc. J. 1973, $34,329$.

3. Ghittori, S.; Imbriani, M.; Pezzagno, G.; Capodaglio, E.; Am. Ind. Hyg. Assoc. J. 1987, 48, 786

4. Dong, I.; Shen, X.; Deng, C.; Anal. Chim. Acta 2006, 569, 91.

5. Kawai, T.; Yasugi, T.; Horiguchi, S.; Uchida, Y.; Iwami, O.; Iguchi, H.; Int. Arch. Occup. Environ. Health. 1990, 62, 409.

6. Bagchi, D.; Bagchi, M.; Hassoun, E.; Stohs, S. J.; Toxicology 1992, 75, 81.

7. Deng, C.; Zhang, J.; Yu, X.; Zhang, W.; Zhang, X.; J.Chromatogr., B: Anal. Technol. Biomed. Life Sci. 2004, 810, 269.

8. Dezwart, L. L.; Venhorst, J.; Groot, M.; Commandeur, J. N. M.; Hermanns, R. C. A.; Meerman, J. H. M.; J. Chromatogr., B: Anal. Technol. Biomed. Life Sci. 1997, 694, 277.

9. Encyclopedia of chemical technology, John Willey \& Sons: New York, 1991, vol. 1, p. 176

10. Krasavage, W. J.; O'donoghue, J. L.; Divincenzo, G. D.; Em Patty's Industrial Hygiene and Toxicology; Clayton, G. D.; Clayton, F. E., eds.; Wiley-Interscience: New York, 1982, p. 4721.

11. Jonsson, A.; Persson, K. A.; Grigoriadis, V.; Environ. Int. 1985, 11, 383.

12. Lipari, F.; Dasch, J. M.; Scruggs, W. F.; Environ. Sci. Technol. 1984, 18, 326.

13. Zervas, E.; Montagne, X.; Lahaye, J.; Atmos. Environ. 2001, 35, 1301.

14. Ernstgard, L.; Sjogren, B.; Warholm, M.; Johanson, G.; Toxicol. Appl. Pharmacol. 2003, 193, 158.

15. Fujino, A.; Satoh, T.; Takebayashi, T.; Nakashima, H.; Sakurai, H.; Higashi, T.; Br. J. Ind. Med. 1992, 49, 654.

16. Jones, A. W.; J. Anal. Toxicol. 2000, 24, 8

17. Wang, G.; Maranelli, G.; Perbellini, L.; Raineri, E.; Brugnone, F.; Int. Arch. Occup. Environ. Health. 1994, 65, 285.

18. Wigaeus, E.; Holm, S.; Astrand, I.; Scand. J. Work Environ. Health. 1981, 7,84 .

19. Brugnone, F.; Perbellini, L.; Apostoli, P.; Bellomi, M.; Caretta, D.; Br. J. Ind. Med. 1983, 40, 160.

20. Treon, J. F. Em Industrial Hygiene and toxicology; Patty, F. A., ed.; WileyInterscience: New York:, 1960, p. 4561.

21. World Health Organization; Isopropanol [Environmental health criteria $n^{\circ}$ 103], WHO: Geneva, 1990.

22. Bailey, D. N.; Clin. Toxicol. 1990, 28, 4459

23. Pappas, A. A.; Ackerman, B. H.; Olsen, K. M.; Clin. Toxicol. 1991, 29 , 11.

24. Zakhari, S.; Leibowitz, M.; Levy, P.; Aviado, D. M.; Isopropanol and ketones in the environment, CRC Press: Cleveland, 1982, p. 3.

25. Ioffe, B. V.; J. Chromatogr. 1984, 290, 363.

26. Jones, A. W.; Sagarduy, E.; Arnqvist, H. J.; J. Anal. Toxicol. 1993, 17,182.

27. Nunez, A. J.; González, L. F.; Janák, J.; J. Chromatogr. 1984, 300,127.

28. Pezzagno, G.; Imbriani, M.; Ghittori, S.; Capodaglio, E.; Am. Ind. Hyg. Assoc. J. 1988, 49, 546.

29. Seto, Y.; J. Chromatogr., A 1994, 674, 25.

30. Vitenberg, A. G.; J. Chromatogr. 1991,556, 1.

31. Brega, A.; Villa, P.; Quadrini, G.; Quadri, A.; Lucarelle, C.; J. Chromatogr. 1991, 553, 249.

32. Ghittori, S.; Maestri, L.; Maraccini, P.; Imbriani, M.; Ind. Health. 1996, $34,409$.

33. Kawai, T.; Yasugi, T.; Mizunuma, K.; Horiguchi, S.; Iguchi, H.; Ikeda, M.; Toxicol. Lett. 1992a, 62, 85.

34. Kawai, T.; Yasugi, T.; Uchida, Y.; Iwami, O.; Ikeda, M.; Int. Arch. Occup. Environ. Health. 1992b, 62, 165.

35. Satoh, T.; Omae, K.; Nakashima, H.; Takebayashi, T.; Matsumura, H.; Kawai, T.; Int. Arch. Occup. Environ. Health. 1996, 68, 147. 